Јован Јерковић

\title{
НЕКЕ ОСОБИНЕ ЈЕЗИКА НАРОДНИХ УМОТВОРИНА У ДЕЛИМА ВОЈВОЂАНСКИХ ПИСАЦА ДРУГЕ ПОЛОВИНЕ ХІХ ВЕКА
}

1. У српској култури XIX века најзначајнија питања била су везана за проблеме усвајања књижевног језика. Њима је испуњено цело прошло столеће (прва половина је обележена Вуковим радом, а друга је у знаку његовог ученика Ђуре Даничића који је научно образложио Вукову концепцију књиж. језика и фонолошког правописа и све до смрти усмеравао њихове токове). Срби су у XIX веку изменили материјалну основу језичког стандарда. Вук се залагао за јединство књижевног језика на бази једног говора, што се у суштини сводило на говор његовог родног краја уз познате корекције које је сам извршио усвајајући особине и неких других говора, односно на језик усмене књижевности као наддијалекатску његову форму. Војводина и Србија нису прихватиле неке Вукове ставове - у формирању књижевног израза пошли су од својих локалних говора иако се Вук према њима односио негативно. Тако су створени услови за две верзије књижевног језика - ијекавску и екавску и овај варијетет прешао је и нама у наслеђе.

2. Српски писци из Војводине чија смо дела узели у разматрање неоспорно припадају Вуку. Друкчије у то време није ни могло бити. Ипак, веза са претходном епохом није никад код њих могла бити покидана - у језику већине писаца с овог подручја срећу се и особитости које их везују за језик предвуковске традиције.

Језик народних умотворина као наддијалекатска форма имао је све предуслове и квалитет стандардног језика, што је недостајало језику претходне епохе. Даничић у свом манифесту 1847. године истиче: „Народна къижевност! Ово је данас велика мисао за којом сва словенска племена листом пристају”... „народне су умотворине сјеме: из тога сјемена треба да нам никне књижевност; то ће само бити права књижевност." (Рат за српски језик и правопис).

О клими која је владала у српској књижевности сведоче нам и речи добрих познавалаца ове епохе: „И зато никада српска књижевност није 
била толико прожета народном поезијом, никада народне песме нису биле тако на цени као тих распеваних и патриотских шездесетих година. Пред навалом свеже народне поезије, класични узори су сасвим ишчезли, немачки стали бледети, књижевност почела добијати национални карактер, ставила се на своју народну подлогу, језик се очистио славеносрпштине, обогатио, улепшао, створио се овај књижевни језик којим се и данас пише и почео се нормални развитак наше књижевности.” „Крајем педесетих и шездесетих година у српској књижевности нема песника који се не инспирише усменом поезијом."

Када говоримо о народној поезији и њеном утицају на писце из Војводине, онда мислимо на друкчију дијалекатску основу јер је огромна већина песама која се у то време нудила као узор била испевана у „јужном" говору.

Књижевни критичари и историчари књижевности када указују на овај утицај, никада не говоре о његовом домету него се, као што смо илустровали, задовољавају општим судовима.

3. Покушаћемо да на разноврсној језичкој грађи писаца из Војводине сагледамо домет овог утицаја на књижевни језик уопште. Своје закључке формираћемо стога на основама анализе песничког језика Б. Радичевића, ${ }^{3}$ прозних дела и сачуваних аутографа Ј. Игњатовића, ${ }^{4}$ Б. Атанацковића, ${ }^{5}$ К. Трифковића ${ }^{6}$ и J. Грчића Миленка, ${ }^{7}$ као и језика писама Ђ. Даничића, ${ }^{8}$ Ђ. Јакшића, ${ }^{9}$ J. Јовановића Змаја ${ }^{10}$ и Ђ. Поповића Даничара ${ }^{11}$.

${ }^{1}$ Јован Скерлић, Омладина и юена књижевност (1848-1871), Београд 1906, 326.

2 М. Поповић, Историја српске књижевности. Романтизам, 3, Београд 1972, 39.

3 Војислав В. Илић, Песнички језик Бранка Радичевића, Матица српска (Нови Сад 1964), $258+16$ аутографа.

${ }^{4}$ Јован Јерковић, Језик Јакова Игъьатовића, Матица српска (Нови Сад 1972), 325.

${ }^{5}$ Јован Јерковић, Језик Богобоја Атанацковића, Матица српска (Нови Сад 1976), 157.

${ }^{6}$ Јован Јерковић, Белешке о језику Косте Трифковића, Зборник за филологију и лингвистику, XVI/2, 75-107.

7 Јован Јерковић, Језик прозних дела Јована Гриића Миленка, Зборник за филологију и лингвистику, XVI/1, 137-173.

${ }^{8}$ Јован Јерковић, О језику Даничићевих писама, Зборник за филологију и лингвистику, XVIII/1, 91-115.

9 Јован Јерковић, Језик у писмима Ђуре Јакщића, Зборник за филологију и лингвистику, XVI/2, 147-171; XV/1, 53-85.

${ }_{10}$ Јован Јерковић, Језик писама Јована Јовановића Змаја, Зборник за филологију и лингвистику, XV/2, 67-115.

${ }^{11}$ Јован Јерковић, Белешке о језику Ђорђа Поповића Даничара, Прилози проучавању језика, књ. 6, 83-104. 
Унапред се може претпоставити да ће језик поезије бити захвалнија грађа за ову врсту испитивања јер је истицано да су честа одступања од „стандардне” ситуације у војвођанским говорима, чија основица видно присутна ујезикусвих наведених писаца (изузимајући Ђ. Даничића), условљена и потребама версификације. Ијекавска замена јата, као најизразитије обележје друкчије дијалекатске основе, могла је често да пружи одговарајући број слогова, о чему су песници српског романтизма водили рачуна. У нашем случају језик аутографа добија посебну вредност. У приватној преписци намењеној пријатељима и рођацима, а она је највећим делом таквог карактера, човек је слободнији и израз му је најприроднији.

Одлучивши се за овакав приступ, били смо уједно свесни сложености проблематике и могућности да се неке особине које се квалификују као црте народних умотворина јављају спорадично и на широј српско-хрватској језичкој територији. Основни критеријум при издвајању црта био је да се таква особитост не налази у литератури о војвођанским говорима (мада су подаци с којима располажемо знатно новијег датума), нити је утврђена као одлика језика писаца претходне епохе.

4. Следећи Вукову концепцију језика, Даничић (1825-1882) је у својим делима усвојио ијекавску верзију књижевног језика. Он је заправо један од ретких екаваца по рођењу који је доследно и с успехом прешао на други изговор. Проблеми на које наилази рођени екавац приликом усвајања знатно компликованијег ијекавског изговора најбоље илуструје грађа Даничићевих писама: у 30 извора налазили смо екавску замену јата, у 18 ијекавску, док се у осталих 11 прегледаних писама наведени рефлекси мешају.

У Даничићевим писмима сретали смо примере типа жељео $(95)^{12}$, наставке -ијех и -ијем у инстр. сг., ген., дат., инстр. и лок. пл.: од свијех ... знанаца, самијех (вас), међу юиховијем хаљинама, у познатијем пјесмама, о... професорима ғьезинијем (95) - облике који представљају посебан вид ијекавизама карактеристичних за херцеговачке говоре. Њих је, као што је познато, каснији развој књиж. језика елиминисао. Прелажење конс. $c>m$ испред $љ$ (добијеног у вези $\pi+j e$ од кратког јата) представља познато ијекавско јотовање које такође не улази у књиж. језик: пошљедюега, поштедюе, пошљедак, на поштетку (97).

12 Уз примере наводимо стране из дела наведених у напоменама од 3-11. 
Присутан је прилог сјутра (96); ${ }^{13}$ морфолошко разликовање количине до 5 и од 5 надаље: Знам да сам неколико свеске послије виђао у Валожићевој књижарници (102); ${ }^{14}$ предлошке конструкције с енклитичким обликом личне заменице, посебно трећег лица: за ме, на се, преда се (99), на юь, за юь, уза юь (100); ${ }^{15}$ који м. чији: Особито вам препоручујем чланке његове у „Књижевнику”, којега ће друга свеска изаћи овијех дана; у којима је бивао П. Лавровски (којега име мислим да је такође стављено међу именима чланова) - стр. $105 .{ }^{16}$ Изложене особине нису својствене језичкој пракси источног подручја.

За „јужне” говоре могу се везивати: лик су м. са: На реченој дипломи имају су двије стране два лика (97); ${ }^{17}$ енклитички облик дат. пл. ви: Бог ви

13 Облик долази у херцеговачким говорима а региструје га и Вук у својој речничкој грађи (Рјечник 1818). Данас се чује у народним говорима наведеног подручја, али и у западним културним центрима. Исп.: „сјутра добар облик, али је обичнији: сутра” (Језични савјетник са граматиком, Матица хрватска, Загреб 1971).

14 Вук је инсистирао на овим разликама и тако изазвао полемику са неким савременицима из Војводине, који су се противили употреби форми неколика и неколике јер их нису имали у свом језику (М. Ивић, Једно поређене Вуковог језика са нашим данашюим књижевним језиком, Зборник за филологију и лингвистику, I, 119).

15 „Енклитички облици ак. ме, me, $c e$, нac, вас не употребљавају се ни у госпођиначком ни у другим бачким екавским говорима уз предлоге. А код Буњеваца их има”... (И. Поповић, Говор Госпођинаца у светлости бачких говора као целине, Београд 1968, 182). Пишући о језику Даничићевог учитеља, П. Ивић констатује: „Систем краћих заменичких облика који се употребљавају уз предлоге с акузативом био је код Вука врло жив и богат формама." (О Вуковом Рјечнику из 1818. године, поговор књизи: Вук Стефановић Карачић, Српски рјечник 1818, Београд 1966, 129).

16 У првом од изнетих примера (заменица се односи на часопис „Књижевник”) била би једино могућа употреба којега; у другом случају очекује се одговарајући облик посесивне заменице чији јер означава лице у муш. роду сг. Наведена правила извео је Маретић полазећи од Вуковог и Даничићевог језика (Граматика хрватскога или српскога књижевног језика, Загреб 1963, 508). Белић и Стевановић указују, међутим, да њихова употреба није у оволикој мери ограничена. Данас се на западу доследније примењује вуковско-даничићевска пракса; на истоку је далеко обичније чији (Белић, Неколико начелних питань, Наш језик, књ. I (1933), 136. и 140; Стевановић, Напоредна употреба који и чији, Наш језик, књ. III, н.с., св. 3, 91-92).

17 Вук у свом Рјечнику (1852) лик су упућује на $c a$, док за примере који су овде дати ( $c y$ дв, cy mри друга) наглашава да су карактеристични за Херцеговину. За војв. говоре помиње га Б. Николић: „Уз то у целом Срему постоји предлог 
дај здравље и свако добро! (100); ${ }^{18}$ ном. сг. хипокористика муш. рода на -о (Ђуро) и један случај промене по првом деклинационом обрасцу: би ме највећма обрадовао... диком црногорском Сима Милутиновића (99); ${ }^{19}$ употреба везника еда: А гледај и с Медаковићем да заметнеш разговор о томе путовању еда бисмо дознали шта он мисли; и исту лексему у функцији упитне речце: и за то бих жељео чути еда ли је у логици паметнији (113). ${ }^{20}$

Утицај народне поезије је свакако био пресудан при усвајању следећих појединости које смо бележили у Даничићевом језику: $c a+$ генитив у исказивању узрока: први лист је штампан два пута $c$ погрешке која је први пут била учињена; У чланку Веберову... нема ништа са чега бисте и најмање промијенили свој суд (105); ${ }^{21}$ употреба аориста несвршених глагола (111);22 наставак двојине у лок. пл. именице рука: „Записке” за које пишете, нијесу ми биле у руку; кад сам имао у руку оригинал при штампању (99). ${ }^{23}$

cy: су тим.., су чим..., ни су чим”... (Сремски говор, Српски дијалектолошки зборник, књ. XIV, 361).

18 „У књижевном језику нијесу узети енклитички облици $н и, в и$ за датив плурала, ни не, ве за ак. плур., које мјесто нам, вам, нас, вас говоре по јужним крајевима" (Маретић, н.д., 191). П. Ивић их наводи и за косовско-ресавске говоре (Дијалектологија српскохрватског језика. Увод у штокавско наречје, Матица српска, Нови Сад 1957, 101), а присутни су и у говорима централног дела западне Србије (исп. М. Николић, Говор Горобила, Српски дијалектолошки зборник, XIX, 675).

19 Тип Јово/Јова карактеристичан је за југозападне и централне шток. говоре (исп. И. Поповић, О именицама Јово и Раде, Питања савременог књижевног језика, год. IV, књ. 2, Сарајево 1952, 243-253).

${ }_{20}$ Рјечник хрватскога или српскога језика ЈАЗУ потврђује његово присуство у писаним изворима од XVI века; међу примерима који се наводе као потврда има их доста из усмене књижевности. Исп.: „заст. 1. везник камерни; да; 2. речца, покр. а) упитна: да ли, има ли”... (Речник српскохрватскога књижевног језика, Матица српска - Матица хрватска, Нови Сад - Загреб, 1967).

${ }^{21}$ Исп. примере из Вуковог језика које наводи Д. Гортан-Премк (Падежне узрочне конструкиије код Вука, Јужнословенски филолог XXVI, св. 1-2, 446) као и стихове нар. песама: Ја ћу с тебе изгубити главу; Није мени са снијега зима/ већ је мени с моје мајке зима.

${ }_{22}$ М. Стевановић указује како је он чест у језику нар. поезије, као и у Вуковом и Даничићевом преводу Библије (Функиије и значена глаголских облика, САНУ, Београд 1967, 79).

${ }_{23}$ Облик некадашњег дуала у лок. пл. Маретић потврђује примерима из језика нар. поезије и Даничићевог дела. Он даље истиче: „у језику Вукову нијесам томе нашао ни једне потврде." (н.д., 178). 
Иако је по обиму грађа прегледаних аутографа мала, ипак даје довољно индиција да се тврди како је Даничић градио свој језик на основама говора на коме је испеван и највећи део наше народне поезије. Додали бисмо да у прегледаној грађи нема ни једног дијалектизма који би га везивао за говоре родног краја, што се тумачи Вуковим односом према њима.

5. Даничићев вршњак Бранко Радичевић (1824-1853) такође је припадао најужем кругу „Вукове деце”. За његов песнички језик Ђ. Даничић каже да је „као суза - чист” (Подунавка, 1847). Исти аутор је констатовао и следеће: „У тежњи да влада књижевним језиком народних умотворина, било је код Бранка много свесног."24

Бранков песнички језик представља мешавину локалног говора, ${ }^{25}$ особина Вуковог језика и језика народне поезије. Песник је, даље, свесно бирао, стварао синтезу са веома широког терена штокавских говора комбинујући често дијалекатске и књижевне облике у естетско-стилске сврхе и тако градио своју језичку и уметничку креативност. У овако општем прилазу у могућности смо да истакнемо само извесне специфичности за које смо уверени да су у Бранков језик првенствено ушле под утицајем језика фолклорне књижевности, мада могу да буду и директно угледање на Вука, али додуше не само на њега.

У Бранковим песмама среће се (и)јекавска замена јата: звијезде, nослије, вријеме, ријечи; звјездице, вјере, пјесама, дјевојака, потјеру (55-56). Он има и ликове: ђецу, приђене, вође (55) који не улазе у норму ијекавске верзије нашег књижевног језика (с напоменом да је у другој књизи песама (1851) предност давао формама са $\partial j$ и $m j .{ }^{26}$ И Бранко се придружује Даничићу с употребом наставака -ијех и -ијем: горскијех хајдука, турскијех пушака, некијех врата, овијех дана, живијем огњем, сјајнијем звјездама (55-56, односно 120-121).

За случајеве проширења основе вокалом $a$ (углавном условљених потребама версификације) песник је инспирацију могао наћи и у Ву-

${ }^{24}$ Цитат преузет из књиге: Војислав В. Илић, Песнички језик Бранка Радичевићa, Матица српска, Нови Сад 1964, 281.

25 „И поред тога што је Караџић тражио извесну уједначеност језика, чак и његов први ученик, Бранко Радичевић, пропуштао је кроз своје песме многе особине војвођанског говора које се нису налазиле у језику Вукову. Главно је био народни дух." (А. Белић, Напомене о данашњим задацима книжевног језика, Наш језик, књ. І н.с., св. 3-4, 77).

${ }^{26}$ Вук је 1839. г. заменио облике ћерати и ђевојка облицима тјерати и дјевојка (М. Павловић, Значај 1839. године у формирану српскога књижевног језика, СКГ, н.с. I VIII, св. 8, Београд 1939, 464-470). 
ковом Рјечнику (1818): савикао, односно сајахо, саурвало (се), савезаше (62), док се за испуштање истог вокала као у примеру: шчекасмо се (62) можемо позвати на стих народне песме: Те не смедо шчекати Богдана.

Сажимање оo > o после губљења консонанта: доше (= дођоше), поше (= пођоше), проше (= прођоше) и сл. (стр. 64. и нап. 58); основа (не) море (74); форме отај, ота, ото: отај јад, ота речца, ото време (109-110); ${ }^{27}$ појава партикуле -зи уз придеве: светојзи, клетојзи, уци пређашғојзи (122); облици: разнесао, донесао, нанесао и сл., где је у основи стари инфинитив нести (139-140); употреба прилога инако: Лепо тако, па лепо инако (159) својствено је и језику народне поезије.

Поред наведених особина запазили смо и придев силени: Силени јад, силенога Бога (117), који је окарактерисан као „стајаћа” реч; у песнички језик улазе и облици: нојиа, нојце (74) где се место $\hbar$ сpeће $j ;{ }^{28}$ licentia poetica представља употреба вокатива у функцији субјекта: Њега зваху змају Милутине; Шкрипи зубим’ Арслан Сулејмане; Већ прискочи проклети Турчине (157); као и намењивање акузатива (објекта) генитивом у примеру: дан све данка, светац свеца-, месец гони све месеца (151); ${ }^{29}$ односно случајеви слагања предлога $y, н a, y 3$, под, за с генитивом место очекиваног акузатива: Како амо у града корачи; Тужан иде он на гроба; И за стола седа; Небу дићи, тамо под облака; Њега нагне уз извора (167).

У нар. поезији Бранко је могао добити инспирацију и за исказивање узрока конструкцијом $c(a)+$ генитив: $C$ јабуке су наше муке / Ca юих, кажу, рај пропаде; Ноћ вам дође са Вука једнога, / Данак бели, браћо, ca другога (165); за широку употребу енклитичких облика акуз. личних заменица с предлозима: на те, на ме, са те, по те, на се (178-179); за многобројне примере аориста (па и од несвршених глагола) и имперфек-

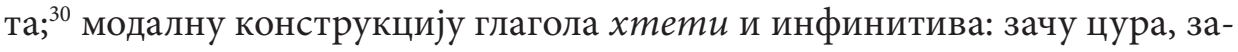

27 У Рјечнику (1852) Вук под одредницом ото даје два примера из народних песама; облике за муш. и жен. род не наводи.

${ }_{28}$ Вук је у Рјечнику (1852) потврђује примером из народне песме. Потврде које даје Рјечник хрватскога или српскога језика ЈАЗУ такође су из поезије. Т. Маретић их узима као особине јужних говора (н.д., 49).

29 У говорима Срема само уз глагол питати долази и генитив (Б. Николић, н.д., 348). Поред глагола пuтати код Вука генитив долази и као допуна неких других глагола (П. Ивић, О Вуковом Рјечнику из 1818. године, поговор књизи: Вук Стефановић Карачић, Српски рјечник 1818, Просвета, Београд 1966, 146).

${ }^{30}$ Не би се, међутим, смела искључити ни веза са претходном епохом: „И перфекат је у Доситеја најобичније прошло време; налази се чешће него аорист и имперфекат." (Сучевић, Језик у делима Доситеја Обрадовића, Извештај правосл. велике гимназије ср. карловачке за школску годину 1913/14, у Сремским 
трепета / Ћаше ymeћ лепа; А он слушо, осмехнут се ћаше! / Али смили па дар доваташе - у значењу: „утекла би”, „осмехнуо би се” (131-132); често изостављање помоћног глагола у перфекту Илић у монографији тумачи угледањем на језик народне поезије (132).

За стари дативски плуралски облик Турком, јунаком (102-103) Илић претпоставља да је могао бити преузет из народних песама, ${ }^{31}$ док се форме не < неје: Ко тебека никад не видео; Ал' га мајка не пустила (144) и нu < нuје: Ма нико је ни назрео (144) срећу и у језику старијих писаца, а својствене су и Вуку.

Одлику југозападних говора представља ген./акуз. личне заменице 3. л. сг. жен. рода юе, је м. присвојне заменице юен: Помоз' Боже, юе големом јаду; Да л' на ћерку юе љувену?; Ма узалуд све юее муке (176) и прилог npeђ (152).

И Бранко речцу еда употребљава у упитним реченицама: Еда ли га валовита/ Бурна вода занела?; Еда ли је громовита/ Ударила га дегод стрела? (201-202), што смо истакли као карактеристику језика Ђ. Даничића (в. т. 4).

И да нагласимо: у прегледу су изостале све особитости које карактеришу шумадијско-војвођанске, и уже - сремске говоре, као и оне које се могу третирати као „славонске”, „ресавске”, „црногорске”, „дубровачке” итд., мада се за неке од њих потврде могу наћи и у језику народне поезије.

6. Богобој Атанацковић (1826-1858), „отац српске новелистике”, у Бечу се прикључио Вуку, а блиски пријатељи су му Б. Радичевић, Ђ. Даничић, Св. Милетић и други из круга Вукових присталица. Књижевни критичари истичу да се у неким његовим делима огледа и непосреднији утицај народне поезије из које позајмљује мотиве и низ појединости.

Карловцима, 62/1914, књ. 55, 38). Ми бисмо прихватили гледиште М. Стевановића (Савремени српскохрватски језик - Граматички системи и кюижевнојезичка норма, II, Београд 1969, 628-630, 633-634) и М. Ивић (н.д., 116) који истичу да је у њиховом поновном оживљавању видну улогу одиграо језик усмене народне књижевности.

${ }^{31}$ Вук је у деклинацији војв. говора бележио и следеће облике дат. пл.: Воловом, соколовом, иарем, пријательем и сл. (Граматички и полемички списи, Београд 1894-1895, 35). За савремене говоре Срема Б. Николић истиче: „архаичног облика дат. пл. на -ом (воловом) нема у Срему" (н.д., 337); њих је, међутим, И. Поповић бележио у Сивцу, дакле у северозападним бачким говорима који су у сталном контакту са буњевачким (Говор Госпођинаца у светлости бачких говора као иелине, Београд 1968, 8). 
Списак особина које га везују за језик народних умотворина (Вука Караџића) веома је оскудан. У његовом делу запазили смо мањи број (и)јекавизама: сјетне, завјесе, предсједник, односно биљежио, насъедство юега, с напоменом да нема рефлекса дугог јата (37-38); понеку именицу за завршетком -о у ном. сг.: Јозо, Иво и др., док само изузетно парадигматски индикатор може да буде и муш. рода: у баба твога (62), што уосталом одговара и говору родне Баје; а и појава енклитичких облика акуз. сг. личних заменица с предлозима може се везивати за најближе бачке буњевачке говоре: на ме, уза се (64).

Висок проценат употребе аориста (релативно чест и од несвршених глагола) и имперфекта (стр. 73-75, 124-125) везује Атанацковића и за језик нар. поезије, али чини и спону с писцима претходне генерације (претходних генерација) в. нап. 30. Иста напомена може се дати и за употребу глаголских прилога, садашњег и прошлог, и у реченици са тзв. „логичким" субјектом: Као да му срце пуца говорећи те речи, замисли се мало; Путник видевщи то, сине му идеја $(128,130) .^{32}$

Насупрот томе Б. Атанацковић је радо преузимао реченице и фразе из народне поезије: ронећи сузе низ своје бело тище; није благо ни сребро ни злато; Није благо ни сребро ни злато, нит су благо грочи и дукати, већ је благо што је сриу драго; мрки брии и страшно оружје; Онда било сад се приповеда; Нама браћо здравле и весеље; Скочи сада на ноге тагане; И јесте боље не имати од сриа порода; Нема смрти без суђена дана; А, многу је уцвелио мајку, многу сестру у ирно завио, јер је многе погубио душе, само да им отме благо и сермију (133-134).

Његово дело није лишено турцизама (речи из турског језика) за чије је присуство, претпостављамо, пресудан утицај имао језик народне књижевности, али напомињемо да се највећи број међу њима и данас употребљава на врло широкој територији српскохрватског говорног израза (135).

7. Творац српског реалистичког романа, Јаков Игњатовић (18221889) није припадао кругу „Вукове деце”. Рођен у најсевернијој оази српскохрватског говора био је с једне стране свестан свог недовољног познавања матерњег језика, а с друге, спадао је међу оне који су се одушевљавали језиком фолклорне књижевности. ${ }^{33}$

32 Говорећи о овим конструкцијама, М. Стевановић између осталог каже: „Већ по томе што се ти примери из народних умотворина појављују код свих граматичара"... (Савремени српскохрватски језик- Граматички системи и кюижевнојезичка норма, II, Београд 1969, 714-715).

33 Ј. Игњатовић, Рапсодије из прошлости српског народа, Мемоари, Матица српска (Нови Сад 1958), 297, 421. и другде. 
У његовом језику присутан је нешто већи број (и)јекавизама: гдје, овдје (58), прије, нијесу, вријеме (65), односно: двје, рјеч, дјете, рједко (65), Ђе, ђеца, онђе, у међедовој кожи (66), итд., што се првенствено везује за говор родног краја. ${ }^{34}$ Наставак -ијех: дванаест жутијех дуката (142) забележен је свега једном у примеру који је под непосредним утицајем народне поезије.

Наставак -о долази у ном. сг. двосложних хипокористичких формација: Паво, Јово, Вујо, Софро, Тимо, Иво (126), док се у косим падежима срећу само облици - $а$ промене; присутни су многобројни енклитички облици личних заменица у акуз. сг. с предлозима: за ме, на те, за ғы, на $c e, y c e$ (137); облици аориста, па и од глагола имперфективног вида, и имперфекта (164-166) - који се, као што смо констатовали, могу само делимично тумачити као утицај језика фолклорне књижевности.

Исказивање узрока конструкцијом предлога $c a+$ генитив: Допале му се Гривићка и Чевићка са своје памети и оштроумља; Милош је био ca доброте своје омиљен и поштован (215); употреба према + генитив: Особито (ју је) уважавао због њене наклоности према Бранковићевог рода; Контрасно је изгледао према оне веселе двојище (216); ${ }^{35} 3 a+$ генитив у служби временске одредбе: а за нашег калфоваға ни калфа није смео пушити (222); двоструки датив: син Марко док је до јуратства дошао, потрошио јој удовици половину имања (223);36 конструкција датива с инфинитивом: Није требало Ђоки у кујну изићи; Сад, господине, шта нам је чинити (223); предлог међу с енклитичким обликом повратне заменице се: Милан и Кузма разговарају се међу се; Никада се не састају, а ужасни рат међу се воде (246); што у функцији инструментала заменице који: отиде свом оцу, те иште маказе што се вуна стриже (259) и др. могу

34 „Присуство одређених икавизама у североисточним српским говорима с екавском основицом сасвим је нормално, али прилично бројни јекавизми представљају специфичну црту и сведоче о знатном уделу мешавине у формирању овог говора, као и говора других српских сеоских насеља у будимпештанској околини који имају мање-више исту особину." (П. Ивић, О српском говору у селу Ловри, Studia slavica Academiae Scientiar Hungariae, Budapest 1966, 194).

35 Према + генитив је и данас у употреби у говорима на југозападу штокавске територије. Регистрован је и у Вуковом језику, али само спорадично, што сведочи да је већ у то време почео да губи књижевни карактер (исп. М. Стевановић, Језик у Вукову делу и савремени српскохрватски книжевни језик, Јужнословенски филолог XXVI, св. 1-2, 116).

36 Двоструки датив (именица и присвојна дативска енклитика) има и Вук (П. Ивић, О Вуковом Рјечнику из 1818. године, поговор књизи: Вук Стефбановић Карачић, Српски рјечник 1818, Просвета, Београд 1966, 147). 
се везати не само за језик нар. поезије и језик Вука Караџића, већ и за одређене народне говоре, а долазе на неки начин и као продужење књижевне традиције.

Списак речи из турског језика код Игњатовића је знатно богатији но што нам пружа литература о говору пишчевог родног краја.

8. Један од најзначајнијих представника српског романтизма, Ђура Јакшић (1832-1878) својим животом и радом везује се за две средине војвођанску и србијанску.

У језику његових писама сретали смо спорадичне (и)јекавизме: дјела, предјел; сльедеће, следовати, тьетопису; односно пльен (161); забележен је свега један пример хипокористичких образовања на -о: Кнез-Лазо (56), вероватно преузет из нар. песме; чести су и облици аориста (64); о конструкцијама типа: зағ, нағ' (58) и исказивању узрока генитивном синтагмом с предлогом $c(a)$ : Срби ако пропадну пропашће са себичности и са подлости (73) констатовали смо да су карактеристични и за језик нар. поезије.

М. Поповић истиче како Јакшићев језик садржи мноштво епитетских синтагми типа: злаћене токе, жарка тубав, русе главе, бело стадо и сл., својствених народној лирици, односно изразе из народне епике типа: крвав делија, льута крајина и сл., ${ }^{37}$ које у приватној преписци, разумљиво, нисмо налазили.

9. Други велики бард српског романтизма, Јован Јовановић Змај (18331904), посвећивао је своме језику посебну пажњу. ${ }^{38}$ „За Змаја би се могло рећи да је, као и Б. Радичевић, имао култни однос према Вуку Караџићу и народној поезији.” И даље: „Змај ће се у свим својим песмама непосредније ослонити на песнички језик народне поезије но Јакшић и Костић." 39

Списак особина који би његову преписку могао везивати за језик нар. поезије веома је скроман: ређи (и)јекавизми: прадједу, бијаху, љетопис (82), конструкције: за ме, на ме, за те, за се, за ғы, на юь (92), релативно жива употреба аориста (97), $c a+$ генитив у означавању узрока: то су разлози са којих сам замолио допуст; са горних околности... морао сам обећати (103, али скрећемо и пажњу да све случајеве треба прихватити с резервама које смо напред износили).

37 М. Поповић, н.д., 107-108.

38 „Осећајући да недовољно познаје народни језик, који је у његово доба увелико постајао књижевни језик, Змај је, као и Бранко Радичевић у пуном смислу речи изучавао и учио Српски рјечник Вука Караџића, и, штавише, и сам се бавио скупљањем речничке грађе (1896 поднео је Матици српској збирку од 3000 народних речи"... (Ј. Скерлић, Историја нове српске књижевности, Рад, Београд 1953, 282).

${ }_{39}$ М. Поповић, н.д., 182. 
Вршећи компарације између песничког језика Б. Радичевића и J. Јовановића Змаја, В. Илић истиче како и Змај у својим песмама има облике: тамнијех понора, твојијех уста (56), wћax, wћаше (135) и др., но на набрајању примера и њиховој анализи овога пута се не бисмо задржавали.

10. Ђорђе Поповић Даничар (1832-1914), публициста, књижевник, преводилац, лексикограф, уредник познатих часописа (Седмииа, Даниu,a), „један од најистакнутијих и најспособнијих Срба свога времена" готово да и нема особина које би га директније везивале за језик фолклорне књижевности.

Из језика његове преписке издвојили смо конструкције: за ме, на $m e$, за се (94); констатовали да је аорист доста жива категорија и побројали неколико турцизама, дакле особине које се и не морају директно везивати за језик нар. поезије.

Даничар употребљава везник оли који Вук у свом Рјечнику (1852) везује за југозападне крајеве и потврђује са више примера из језика народних песама: јера иначе хоћемо ми твоји пријатељи овде држати, $e$ си се од нас понео, оли напоследку на нас заборавио (101); везник е с узрочним значењем (дат у претходној реченици) Вук узима са југоисточног дела штокавске територије и такође поткрепљује стиховима из народне поезије (Рјечник 1852).

11. У литератури се о комедиографу Кости Трифковићу (1843-1875) констатује да се у првим његовим песмама осећа директан утицај српске романтичарске поезије и народних песама које је Вук презентирао свету. У аутографима (већи одломак рукописа Дневник) и објављеној прози (путописи и приповетке) из којих смо разматрали грађу, издвојили смо следеће појединости: спорадични ијекавизми: двије, у предјелима, побједили, посјетити, жельезнииу, усъед, одољети, посљедни дана, юежно, односно ниђе, пљен (83-84), хипокористичка образовања муш. рода на -о и спорадични облици истих именица по првој деклинационој врсти: Гобо, Гоба, Гобу... (91), ређи примери конструкција: на ме, на те, изаю (92), релативно чест аорист и имперфекат (96-97); исказивање узрока везом сa + генитив: Био сам са ғе врло несретан; Која би се... могла назвати палатом са своје пространости и свога положаја (99) као и употребу везника $e$ : Ведро и отворено погледаху један другоме у очи, обојици беше мило, $e$ су се разумели и заверили (99).

12. Јован Грчић Миленко (1846-1875) најмлађи је писац са нашег списка. Књижевни историчари истичу да се и у његовој поезији осећа утицај народних песама. ${ }^{40}$ У објављеним прозним радовима и писмима,

40 М. Поповић, н.д., 419. 
грађи коју смо прегледали, од језичких црта које се могу везивати за народну поезију издвојили смо следеће: само један случај ијекавске замене jата - прије (146), употребу предлога уз акуз. сг. личних заменица: $y$ me,

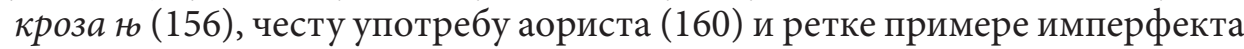
(161), као и једини пример везе $c a+$ генитив у исказивању узрока: Завртим главе тол'ким нашим мужевима, са којих нас је сад већ и срам (165).

13. Вукова реформа у којој народне умотворине имају непроцењив значај постала је основа за брзо и самостално формирање оригиналне књижевности у ужој словенској и широј европској заједници. Духом народне поезије прожето је стваралаштво српских писаца друге половине XIX века, што се свакако одржавало и у њиховом језику.

Списак особина које смо прикупили из веома разноврсне грађе потврђује да је процес превирања у нашем књиж. језику трајао дуже време. Вуково становиште за које се залагао и Ђ. Даничић нису прихватили српски писци из Војводине остајући у основи верни свом локалном говору. Наша уско постављена филолошка истраживања, а и сам избор грађе, нису довољни да истакну сложене аспекте и деловање језика народних умотворина у књижевноуметничкој употреби (на који аспект нам указују књижевни критичари и историчари књижевности). Ограничавање на лексичко-граматички ниво језика показало је како је утицај језика народне поезије на језички израз војвођанских писаца у другој половини прошлог столећа више него скроман. Гледано из перспективе развоја савременог језичког стандарда екавске верзије, брзо се показало да језик фолклорне поезије није погодан узор за образовање модерног књижевног језика. Прави узор могао је да буде живи свакодневни говор са знатно богатијом лексиком и развијенијом синтаксом, онај који је био отворен према цивилизационим токовима у које се интегрисала и српска култура. 